\title{
The relationship between self-efficacy and the duration of students' final project writing completion
}

\author{
1Nafisa Syahida Rahmadini ${ }^{*}$, ${ }^{2}$ Hartono, and ${ }^{3}$ Rohmaniyah \\ 1,2,3English Education Department, Language and Communication Science Faculty, \\ Sultan Agung Islamic University \\ Semarang, Indonesia \\ *Corresponding Author \\ Email: Nafisasyahida1412@gmail.com
}

\begin{abstract}
This study is aimed at finding out the relationship between self-efficacy and the duration of students' final project writing-commonly reffered as skripsi-completion. It was a correlational study involving 33 students of English Education and English Literature departments of the College of Languages and Communication Science of Sultan Agung Islamic University (UNISSULA) Semarang who were taken purposively as samples for the study. Data were collected by questionnaire of selfefficacy and a respondent-fill-form to collect data on the duration the final project completion. The result of the analysis showed that students' self-efficacy and the duration of their final project writing completion was correlated positively at 0.994. This implies that students with high selfefficacy would likely complete the final project earlier than those with lower self-efficacy.
\end{abstract}

Keywords: students' self-efficacy, final project, skripsi, the duration of students' final project writing completion.
Received:
Revised:
Accepted:
Published:
9 October 2018
27 February 2019
28 February 2019
28 February 2019

\section{INTRODUCTION}

For students of both English Education Department and English Literature Department of College of Languages and Communication Science of Sultan Agung Islamic University which in Bahasa is popularly known as UNISSULA, completing a final project, commonly termed as skripsi, and defending it before the board of examiners is a requirement to earn a degree of undergraduate in their respective majors. In the college, skripsi is a student-must-do final project worth for 6 credits which is expected to be completed within 2 semesters; one semester for preparing the research proposal and having a seminar about it, and the other semester for collecting data, analyzing them, 
Rahmadini, Hartono, \& Rohmaniyah, EduLite: Journal of English Education, Literature, and Culture Vol.4, No.1, February 2019, 87-100 DOI: http://dx.doi.org/10.30659/e.4.1.87-100

writing final draft and having it examined before the board of examiners set by the study program.

During the process of the writing until the examination, a student was supervised by a lecturer appointed and assigned by the program to guide, provide advice and consultation and act as a member of the board of examiners. For students of English Education Department of UNISSULA, the topics of the final projects mostly are related to foreign/second language learning and teaching, material designs, language assessment and the like, while for students of English Literature major, literature analysis is a common topic. It is written in English and consists of 5 chapters of Introduction, Review of Related Literature, Research Method, Result and Discussion, and Conclusion and Recommendation, and bibliography together with other required documents specified in the manual.

Though the term for completing the final project is 2 semesters, some students fail to complete it in time. Research topic mastery or the what to write' issue, and student language competence and writing skill or 'how to write issue' are common problems facing many students of both majors. For some especially students who are not well-prepared for it, writing final project is really 'threatening' and has impeded them to finish their study within 8 semesters as stipulated in the curriculum.

Although all students taking final project have got required courses as research method in ELT, academic writing, statistics, and some mini research projects in their previous, the fear of doing final project doesn't really subside from them. In completion of the final project, students are required to have the ability to formulate problems, collect data, analyze and draw conclusions. They are also required to be able to write the reports in intelligible English and present it before the board of examiners. In some cases, the ability of students to put ideas in good English is still a problem. It can be caused by many factors such as the comprehending of English mastery, the ability of writing skill, vocabulary mastery, so forth.

In addition, there is also another thing that is very influential in completing the final project besides the problems mentioned above namely students' own judgment on their ability, beliefs and confidence that they will be able to accomplish the task of writing final project successfully which is referred as self-efficacy (Bandura, 1997). Self-efficacy strongly influences individual persistence on doing the task. A student with high self-efficacy will likely keep trying to work on the project and keep searching possible solutions for their problems at hand. For example when her supervisor reject her research proposal, she will try to argue and convince them that the topic is worth-researching, or at least she will soon come to see him with a new alternative of topic. On the contrary, a student with low self-efficacy will likely surrender and withdraw easily when a problem(s) occur on his course of doing his final project.

Bandura (1992) in Hashemnejad et al., (2014) states that there are two differences regarding students' self-efficacy, there are students who have high self-efficacy and students who have low self-efficacy. The learners who have high self-efficacy believe that they can find a solution and solve the problem because they have created an idea. They feel confident that their competency will be better when they work hard. They always believe that the result they 
get in accordance with their effort, and they consider a mistake as a lesson. Nevertheless, the learners who have low self-efficacy tend to think that they have innate low ability that make them prefer not to ask the tasks because they assume that they will make same errors; and they believe that it will show their weaknesses. Therefore, they do not want to try hard.

In relation to what has been happening in English Education Department and English Literature Department of College of Language and Communication Science of Sultan Agung Islamic University (UNISSULA), researchers thought that the inability of students to complete the English final project is influenced not only by writing skills, topic mastery, and the academic masters but also the students' beliefs about their ability to complete the task where self-efficacy is one of them. For that reason, the reserachers was anxious to investigate about the relationship between self-efficacy and the duration of students' final project writing completion.

There are some reasons for doing the project. Firstly, the topic is relatively new in Education Department and English Literature Department of College of Language and Communication Science of Sultan Agung Islamic University (UNISSULA). Secondly, the ability of writing in good English still becomes a big problem for university students especially in writing final project. Lastly, the study is expected to help and solve the problem about students' final project writing completion. While the main objective of the study was to find out whether there was a significant correlation between students' self-efficacy and the duration of final project writing completion of the students.

The amount of effort and persistence that a person will invest in a particular task is often associated with their level of self-efficacy. According to Bandura (1997), self-efficacy refers to beliefs in one's capabilities to organize and execute courses of action required to achieve certain performance outcomes. These beliefs are seen as the generative mechanism through which persons integrate and apply their existing, behavioral, and social skills to the performance of a task. It is expressed as personal confidence in the ability to successfully perform tasks at a given level. Another definition, Bandura (1994) states that self-efficacy beliefs determine how people feel, think, motivate themselves and behave. Such beliefs produce these diverse effects through four major processes. They include cognitive, motivational, affective and selection processes. Bandura (2000) mentions that people of high self-efficacy focus on the opportunities worth pursuing, and view problems as surmountable. Through their ingenuity and diligence, they seek ways to exercise control even in environments with limited opportunities and many obstacles. While people with low self-efficacy will dwell on impediments which they view as obstacles over which they can exert little control, and easily convince them of the futility of effort. They achieve limited success even in environments that provide many opportunities.

Bandura (1982) states that judgment of self-efficacy is influenced by people's behavior, their mindset and emotional reactions that they experience in a tough situation for making an effort in the face of obstacles. People with high assurance in the ability can perceive a difficult task as a challenge that must be controlled and not as a threat that is to be avoided. Such an efficacious outlook fosters intrinsic interest and deep engrossment in 
Rahmadini, Hartono, \& Rohmaniyah, EduLite: Journal of English Education, Literature, and Culture Vol.4, No.1, February 2019, 87-100 DOI: http://dx.doi.org/10.30659/e.4.1.87-100

activities. They improve and sustain their efforts in the face of failure. They quickly restore their pretending after failure or a setback. On the other hand, people who doubt their capabilities avoid difficult tasks that they consider as a threat. They slacken their effort and give up quickly in the face of difficulties. They are slow to restore their pretending after the failure or a seat back. They will lose confidence despite their few failures, arguing they see inadequate performance as lacking ability.

According to Goulão (2014) self-efficacy has a significant impact on the definition of goals, and compliance through the influence they exert on individual choice, motivation, resilience, and on emotional reactions. It influences the effort and persistence in performing a given task. It means that self-efficacy influences either the cognitive or the affective dimension of the learning process.

Bandura (1986) states that self-efficacy beliefs develop in response to four source of information. The most powerful influence on self-efficacy is enactive experience in which self-efficacy for a behavior is increased by successfully performing the behavior. The second most powerful influence is vicarious experience in which other similar people are seen to perform a behavior successfully. A third source of influence is verbal persuasion, which, if realistic, can encourage efforts that are more likely to increase efficacy through success. Finally, self-efficacy beliefs can be affected by psychological and affective states such as stress and anxiety.

\section{The relationship between self-efficacy and writing skill}

McLeod in Pajares and Johnson (1994) defines that writing is as much an emotional as a cognitive activity. Affective components strongly influence all phases of the writing process. It defines that in doing writing, a writer involves not only the cognitive aspects but also the affection and many practices to gather the ideas into a piece of writing. It means that in writing, students also involve their affection and emotion. In addition, self-efficacy in writing (Bandura, 1994) is the students' beliefs in their ability to perform written in English (Bandura, 1994).

It can be in the form of the composition, correctly punctuating writing and creating grammatically correct samples of writing. In addition, selfefficacy can help the students to recognize their ability in writing whether as poor writers who tend to perform being reluctant to engage in writing works and making brief or incomplete pieces of writing; or as good writers who can complete writing tasks successfully.

Another definition of writing self-efficacy is proposed by Chea and Shumow (2014) who consider that writing self-efficacy is a student's ability to appear in writing tasks which can be paragraphs, text or others. Therefore, writing self-efficacy will imply a high sense of efficacy in writing. In addition on that, Pajares (2003) argues that self-efficacy can be low and over-inflated. Students with low levels of efficacy will have problems in their learning if they do not apply for confidence. Students with over-inflated self-efficacy levels tend to be risked by over-confident and not using the right way to succeed, the example of the case in writing is; they may not take the time to get the right structure, format, and rules for their writing assignments. 
Flores (2013) states that self-concept and self-efficacy are the things that affect writing performance because they involve students' confidence in their abilities and attitudes to accomplish a given task. In addition, Bandura (1994) mentions that students who evaluate themselves as poor writers tend to perform as relative to engage in writing works and create higher standards. It means that self-efficacy affects the writing performance of a person.

Concerning the relationship between self-efficacy and writing performance, there were studies which could be refer to. The first research was the one conducted by Hashemnejad et al. (2014) entitled "The Relationship between Self-efficacy and Writing Performance across Genders". The purpose of the study was to investigate self-efficacy and writing performance of Makoo and Marand EFL students majoring in Teaching English as a Foreign language (TEFL).

In this study, the data were collected through writing test and a questionnaire (SGSES) on 3 occasions at one week intervals. The total of populations in this research was 120 learners of 20 to 29 years old. To find out the relationship between self-efficacy and writing performance, the participants were required to fill out the SGSES. The instrument used on his study was Sherer et al.'s General Self-Efficacy Scale (SGSES). It was used to assess the participants' self-efficacy. The writing test was selected from the IELTS test.

The results were studied according to a nine-band scale. Each overall band scale points out a descriptive statement which tells a summary of the English language ability of a student categorized at that level. The data were analyzed using Pearson's correlation statistic and independent-sample $t$-test. Results revealed that there was no significant relationship between male and female EFL students' self-efficacy and writing performance. It also found that there was a significant positive relationship in self-efficacy between female and male EFL students. This study expected to contribute to the related literature by shedding light on the relation of student self-efficacy and writing performance.

The second research was conducted by Shah et al. (2011) who did the study about "Self-efficacy in the Writing of Malaysian ESL Learners". The subject of the research was Malaysian secondary school students learning English. The study also examined the relationship between the learners' selfefficacy and their writing performance and competence. As found in this research, there is a significant positive correlation between writing self-efficacy and writing performance in English. However, the correlation between general self-efficacy and writing performance found to only have a medium positive correlation.

\section{METHOD}

The design of this research was correlational. It belongs to quantitative research approach (Saleh, 2008). This study was aimed at finding out the relationship or correlation between students' self-efficacy and the duration of final project writing completion. Therefore, there were two variables, one was students' self-efficacy and the other one was the duration of students' final project writing completion. 
Rahmadini, Hartono, \& Rohmaniyah, EduLite: Journal of English Education, Literature, and Culture Vol.4, No.1, February 2019, 87-100 DOI: http://dx.doi.org/10.30659/e.4.1.87-100

According to Arikunto (2006), subjects are central thing of the study. With the subject, people can collect the necessary data. The subjects of this research were the students of English Education Department and English Literature Department of College of Language and Communication Science of Sultan Agung Islamic University (UNISSULA) who were doing the final project in the academic year $2017 / 2018$ especially the students of semester 7 and 8 .

According to Gay and Airasian (2000) that sampling is the process of selecting a number of individuals for a study in such a way that the individuals represent the larger group from which they were selected. A sample comprises the individuals, items, or events selected from larger group referred to as a population. It means that drawing inference of research is represented of population. Thus, sample must be homogeneous which obviously reflects the population. The sampling technique used in this study was convenience sampling.

According to Etikan et al., (2015), convenience sampling is a type of nonprobability or nonrandom sampling where members of the target population that meet certain practical criteria, such as easy accessibility, geographical proximity, availability at a given time, or the willingness to participate were included for the purpose of the study. The convenience sampling was used in this study because researchers had the criterion of the sample namely the students who doing final projects in the academic year $2017 / 2018$. Therefore, the use of convenience random sampling here was aimed at getting the criterions targetted to be the samples from the population.

The data for this study were collected by using two questionnaires. The first questionnaire was designed to collect information on the estimated duration of the students' final project writing completion. The second questionnaire was the one for collecting information of students' self-efficacy. In collecting the data, researchers used closed-ended questionnaire to measure the students' self-efficacy. The closed-ended questionnaire was used to guide the respondents' opinion based on the statement into a Likert Scale. Sugiyono (2014) proposed that the Likert Scale is used to measure the attitudes, opinions, and perceptions of a person or group of social phenomena. The following is a table example of questionnaire. Therefore, to avoid the students' difficulties in responding the questionnaire, it was written in Bahasa Indonesia.

In this study, researchers took several indicators, namely personality factors (people's behavior, their mindset, emotional reactions, affective domain and motivation), social cultural factors (attitudes, social distance and culture in the classroom), personal factor in foreign language acquisition (grammar and vocabulary) and cognitive (affective dimension of the learning process). The indicators of the questionnaire are shown below: 
Table 1. Indicators of the questionnaire

\begin{tabular}{|c|c|c|}
\hline No & & ndicators \\
\hline 1. & $\begin{array}{l}\text { Personality Factors } \\
\text { (Brown, 2001) }\end{array}$ & $\begin{array}{ll}\text { - } & \text { People's behavior } \\
\text { - } & \text { Their mindset } \\
\text { - } & \text { Emotional reactions } \\
\text { - } & \text { Active domain } \\
\text { - } & \text { Motivation }\end{array}$ \\
\hline 2. & $\begin{array}{l}\text { Social Cultural Factors } \\
\text { (Brown, 2001) }\end{array}$ & $\begin{array}{ll}- & \text { Attitudes } \\
\text { - } & \text { Social distance } \\
\text { - } & \text { Culture in the classroom }\end{array}$ \\
\hline 3. & $\begin{array}{l}\text { Social Cultural Factors } \\
\text { (Adwani \& Shrivastava, 2017) }\end{array}$ & $\begin{array}{ll}- & \text { Grammar } \\
- & \text { Vocabulary }\end{array}$ \\
\hline 4. & $\begin{array}{l}\text { Cognitive } \\
\text { (Bandura, 1994) }\end{array}$ & $\begin{array}{l}\text { - Affective dimension of the learning } \\
\text { process }\end{array}$ \\
\hline
\end{tabular}

According to Best (1981), validity is the procedure that enables it to determine what it is designed to determine the quality of a data-gathering instrument. In this research, the validity of students' self-efficacy questionnaire will provide by using Pearson Product Moment correlation formula. Hence, the score of each item and also the total score will calculate to find out their correlation coefficient. The calculation will use SPSS 20.0 application.

According to Setiyadi (2006), reliability is consistency of questionnaires on how far the questionnaires measure similar subjects in different time, but still show fixed result. To calculate the reliability of the instrument of this study, the study used Cronbach's Alpha Reliabilities Formula for the internal consistency. The reserachers found how many items scale of internal consistency could be used and it would be founded by the SPSS analysis to check the reliability. Setyadi (2006) states that if the Cronbach's alpha score is $>0.7$, it means that the reliability of the items is accepted and they can be used.

In quantitative research, data normality is one of essential points in statistics. The purpose of measuring data normality is to determine whether the instrument can be distributed in the whole population or not. Therefore, it is important before calculating the variables. In calculating data normality, the data are considered to have normal distribution if the data have the probability of $\mathrm{p}>0.05$. Hence, to make easy and more accurate process of calculating the data normality, the reserachers used One-sample Saphiro Wilk of SPSS 20.0 to calculate the normality. In addition, Saphiro Wilk is usually used when the total of respondents is $>50$.

\section{RESULTS AND DISCUSSION}

This study was conducted at students of English Education and English Literature of Language and Communication Science Faculty of Sultan Agung Islamic University (UNISSULA) Semarang who are doing the final project in the academic year 2017/2018 especially the students of semester 7 and 8 from $19^{\text {th }}$ to $27^{\text {th }}$ April, 2018. The number of sample of respondents was 33 
Rahmadini, Hartono, \& Rohmaniyah, EduLite: Journal of English Education, Literature, and Culture Vol.4, No.1, February 2019, 87-100 DOI: http://dx.doi.org/10.30659/e.4.1.87-100

students. It consisted of 6 male and 27 female, there were 8 students from English Literature Department and 25 students from English Education Department.

In collecting the data, researchers used closed ended questionnaire and summed up the item credit of the answers. As mentioned in the previous chapter, each items have five options for the statements: "Strongly Agree" or Sangat Setuju (SS) which is credited 5 points, "Agree" or Setuju (S) which is credited 4 points, "Neither Agree nor Disagree" or Netral (N) which is credited 3 points, "Disagree" or Tidak Setuju (TS) which is credited 2 points and "Strongly Disagree" or Sangat Tidak Setuju (STS) which is credited 1 point.

Pearson Product Moment Correlation formulas in SPSS 20.0 was used to measure the validity of the questionnaire. When Pearson Correlation Sig (2tiled) value is higher than the score of the $r_{\text {table, }}$ an item considered is valid. In this case for the number of samples $(\mathrm{N})$ was 33, $r_{\text {table }}$ was 0.344 . In this research, self-efficacy questionnaire test consisted of 20 items. After the data had been calculated by using Pearson Product Moment correlation formula, the result showed that there were 2 invalid items and 18 valid items. Those were questions number $1,2,3,4,5,6,7,8,10,11,12,13,14,15,16,17,18$, and 19. Below is the description of the result.

Table 2. Validity of the questionnaire

\begin{tabular}{llcc}
\hline No & \multicolumn{1}{c}{ Indicators } & \multicolumn{2}{c}{ Number of Item } \\
\cline { 3 - 4 } & & Valid & Invalid \\
\hline 1 & $\begin{array}{l}\text { Personality factors (active domain, } \\
\text { motivation, people's behavior, their } \\
\text { mindset and emotional reactions) }\end{array}$ & $\begin{array}{c}1,2,4,5,7,10, \\
11,12,14,16, \\
18,19\end{array}$ & \\
\hline 2 & $\begin{array}{l}\text { Social cultural factors (attitudes, } \\
\text { social distance and culture in the } \\
\text { classroom) }\end{array}$ & 13 & \\
\hline 3 & $\begin{array}{l}\text { Personal factor in foreign language } \\
\text { acquisition } \\
\text { vocabulary) }\end{array}$ & 8,17 & \\
\hline 4 & $\begin{array}{l}\text { Cognitive (affective dimension of the } \\
\text { learning process) }\end{array}$ & $3,6,15$ & 2 \\
\hline
\end{tabular}

Reliability is also an important characteristic of a good instrument. The reliability of the instrument was measured by using Cronbach's Alpha in SPSS 20.0. According to Setyadi (2006), if the Cronbach's Alpha score is higher than 0.7 , the questionnaire is and it can be used to collect data. The result showed that Cronbach's Alpha was 0.854, it was higher than 0.7 or $0.854>0.7$, so the instrument was reliable. The table of result of output of SPSS 20.0 can be seen below:

Table 3. Reliability statistics of the students' self-efficacy

\begin{tabular}{cc}
\hline Cronbach's Alpha & N of Items \\
\hline .854 & 18
\end{tabular}


Based on validity point of view, the data from the observation sheet of the duration of students' final project writing could be categorized valid because they was taken and filled directly from the sample of students who filled the questionnaire with the estimated time of the final project completion. For additional information, the table of observation sheet of the duration of students' final project writing completion was listed in the questionnaire sheet. It was intended to facilitate the collection of data simultaneously. As the data collected, then the researchers have converted the estimated time of the final project to be the number of days before doing data analysis.

Based on the curriculum, final project in both English Education Department and English Literature Department is scheduled to be completed within 2 semesters. One semester is for writing the research proposal and having it examined, and the other one semester is for doing experiment, collecting data and the likes, and final examination. Based on the data of the duration of the students' final project completion, the students were able to finish the final project in various durations of time. They were 164, 180, 210, 220, 231, 240, 256, 264, 270, 277, 280, 284, 286, 291, 300, 307, 321, 328, 330 , and 344 days. From the data, it can be seen that the shortest duration of students' final project completion was 164 days, while the longest was 344 days.

In this case, the researchers have obtained the results of the data from 7 and 8 semester of English Education Department and English Literature Department of Language and Communication Science Faculty of Sultan Agung Islamic University (UNISSULA) especially students who were finishing the final project. To test the correlation, the data should be normally distributed. So that, the researchers had done the normality test before doing the correlation test.

Researchers had to measure the data normality before both students' self-efficacy and the duration of final project writing completion data were calculated. If the data were normal, the result of the study could be generalized to the whole population. The data normality was calculated by Shapiro-Wilk Test SPSS 20.0. Shapiro-Wilk Test was used because the sample of the data was smaller than 50. The null hypothesis says if the value of The Saphiro-Wilk Test is bigger than 0.05, so the data is normal. If the value of of the Saphiro-Wilk Test is smaller than 0.05, so the data is not normal. Table below shows the normality distribution.

Table 4. Tests of normality

\begin{tabular}{llcrrrr} 
& \multicolumn{3}{c}{ Kolmogorov-Smirnova } & \multicolumn{3}{c}{ Shapiro-Wilk } \\
\cline { 2 - 7 } & $\begin{array}{l}\text { Statist } \\
\text { ic }\end{array}$ & Df & Sig. & Statistic & Df & Sig. \\
\hline $\begin{array}{l}\text { Students Self- } \\
\text { Efficacy }\end{array}$ & .084 & 33 & $.200^{*}$ & .980 & 33 & .788 \\
\hline $\begin{array}{l}\text { The Duration } \\
\text { of Students' }\end{array}$ & .057 & 33 & $.200^{*}$ & .987 & 33 & .948 \\
$\begin{array}{l}\text { Final Project } \\
\text { Writing }\end{array}$ & & & & & & \\
Completion & & & & & \\
\hline *. This is a lower bound of the true significance. & & & \\
\hline a. Lilliefors Significance Correction &
\end{tabular}


Rahmadini, Hartono, \& Rohmaniyah, EduLite: Journal of English Education, Literature, and Culture Vol.4, No.1, February 2019, 87-100 DOI: http://dx.doi.org/10.30659/e.4.1.87-100

The table 4 showed that Sig (2-tailed) 0.788 for students' self-efficacy and 0.948 for the duration of students' final project writing completion. The score of the Saphiro-Wilk of students' self-efficacy is bigger than 0.05 , so $\mathrm{H}_{0}$ is accepted. And also, the value of the duration of students' final project writing completion is higher than 0.05 , therefore, $\mathrm{H}_{0}$ is accepted. It can be concluded that the data distribution of both the students' self-efficacy and the duration of students' final project writing completion were normal.

Next, researchers analyzed linearity of the data to know whether the data to be correlated is linier. Researchers used table Anova. The null hypothesis says if the value of deviation from linearity was bigger than 0.05 . It means that the data is linier. If the value of Linearity is smaller than 0.05 , so the data is not linier. Table below shows the linearity of the data.

Table 5. Test of linearity

ANOVA Table

\begin{tabular}{|c|c|c|c|c|c|c|c|}
\hline & & & $\begin{array}{l}\text { Sum of } \\
\text { Squares }\end{array}$ & $\begin{array}{l}\mathrm{d} \\
\mathrm{f}\end{array}$ & $\begin{array}{l}\text { Mean } \\
\text { Square }\end{array}$ & $\mathrm{F}$ & Sig. \\
\hline Self-Efficacy & Between & (Combined) & 1582.820 & 2 & 184.51 & 5.52 & .001 \\
\hline * The & Groups & & & 0 & 2 & 1 & \\
\hline $\begin{array}{l}\text { Duration of } \\
\text { Students' }\end{array}$ & & Linearity & 1499.876 & 1 & $\begin{array}{r}1499.8 \\
76\end{array}$ & $\begin{array}{r}48.0 \\
16\end{array}$ & .000 \\
\hline Final Project & & Deviation from & 186.046 & 1 & 32.802 & .746 & .759 \\
\hline Writing & & Linearity & & 9 & & & \\
\hline
\end{tabular}

\begin{tabular}{llll}
\hline Within Groups & 538.875 & 1 & 28.776 \\
& 2 & \\
\hline Total & 2721.667 & 3 & \\
& & 2 & -
\end{tabular}

The table 5 shows that sig is 0.746 . The score of deviation from linearity is bigger than 0.05 , thus, therefore, $\mathrm{H}_{0}$ is accepted. It means that the relationship between self-efficacy and the duration of students' final project writing completion was linear.

After the data have been proven normal, the next step the researchers analyzed correlation between both of the data students' self-efficacy and the duration of students' final project writing completion. The main goal of this study was to find out whether there was or there was no correlation between self-efficacy and the duration of students' final project writing completion. The statistics parametric was used to analyze the correlation in this study. Thus, the Pearson's product moment in SPSS 20.0 was used to compute correlation between the two variables.

The data to compute the correlation between self-efficacy and the duration of students' final project writing completion were obtained in 
appendix pages. From the data we could find out the values. Then, the data above is put in the formula of Pearson Correlation and the result is as follows:

Table 6. Correlation between self-efficacy and the duration of students' final project writing completion

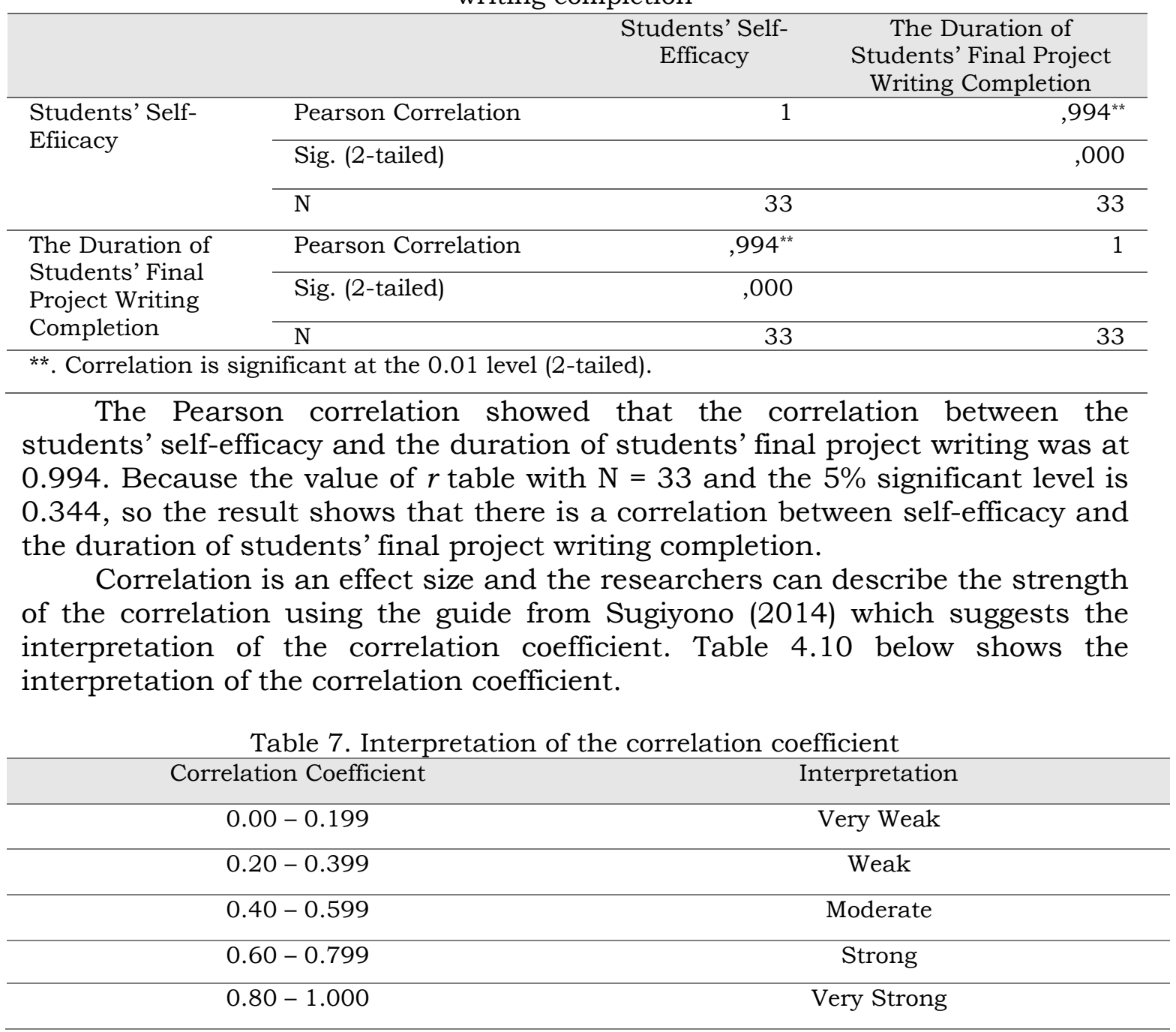

The value of coefficient correlation is 0.994. It is between $0.800-1.000$. It means that the degree of relationship is very strong. Thus, the significant relationship of self-efficacy and the duration of students' final project writing completion was very strong.

\section{CONCLUSION}

Based on the results of the discussion on the previous chapter, it can be concluded that there was a correlation between self-efficacy and the duration of students' final project writing completion of 7th and 8th semester of the students of English Education and English Literature Department of College of Language and Communication Science of Sultan Agung Islamic University (UNISSULA) in $2017 / 2018$. It was proven that there was a significant correlation between both of data. The result showed that the coefficient 
Rahmadini, Hartono, \& Rohmaniyah, EduLite: Journal of English Education, Literature, and Culture Vol.4, No.1, February 2019, 87-100 DOI: http://dx.doi.org/10.30659/e.4.1.87-100

correlation was bigger than the score of $r$ table or $0.994>0.344$. The coefficient of the correlation was 0.994 . It is between $0.800-1.000$. It means that the self-efficacy and the duration of students' final project writing completion were strongly correlated. From that result, the null hypothesis $\left(\mathrm{H}_{0}\right)$ was rejected and the research hypothesis $\left(\mathrm{H}_{1}\right)$ was accepted. 


\section{REFERENCES}

Adwani, P., \& Shrivastava, S. (2017). Analysis of Factors Affecting Second Language Acquisition. International Journal of Social Sciences and Management, Vol. 4, Issue-3.

Arikunto, S. (2006). Prosedur Penelitian Suatu Pendekatan Praktik. Jakarta: Rineka Cipta.

Bandura. (1986). Social foundations of thought and action: A social cognitive view. Eaglewood Cliffs: Prentice Hall.

Bandura, A. (1982). Self-efficacy Mechanism in Human Agency. U.S.A: American Physicologist.

Bandura, A. (1992). Self-efficacy mechanism in socio cognitive functioning. The American Educational Research Association annual meeting.

Bandura, A. (1994). Self-efficacy. New York: Academic Press.

Bandura, A. (1997). Self-efficacy: The exercise of control. New York: Freeman.

Bandura, A. (2000). Cultivate Self-efficacy for Personal and Organizational Effectiveness . Oxford, UK: Blackwell.

Best, J. W. (1981). Research in Education Fourth Edition . New Jersey: PRENTICEHALL INC.

Brown, H. D. (2001). Teaching by Principles: An Interactive Approach to Language Pedagogy. New York: Addison Wesley Longman, Inc.

Chea, S., \& Shumow, L. (2014). The Relationships Among Writing Self-Efficacy, Writing Goal Orientation, and Writing Achievement. Language Education in Asia, Volume 5, Issue 2.

Dornyei. (2007). Research Method in Applied LInguistics: Quantitative, Qualitative, and Mixed Methodologies. Oxford: Oxford University Press.

Etikan, I., Abubakar Musa, S., \& Sunus, R. (2015). Comparison of Convenience Sampling and Purposive Sampling. American Journal of Theoretical and Applied Statistics.

Felor Hashemnejad, Masoud Zoghi, Davoud Amini. (2014). The Relationship between Self-efficacy and Writing Performance across Genders. Theory and Practice in Language Studies, Vol. 4,.

Flores, E. R. (2013). Self-Concept and Self-Efficacy Beliefs as Predictors of Writing Performance of College Freshman Students. Research Congress 2013.

Gay, R., L., \& Airasian, P. (2000). Educational Research : Competencies for Analysis and Aplication Sixth Edition. New York: Practice-Hall, Inc.

Goulão, M. d. (2014). The Relationship between Self-Efficacy and Academic Achievement in Adults' Learners. Athens Journal of Education. 
Rahmadini, Hartono, \& Rohmaniyah, EduLite: Journal of English Education, Literature, and Culture Vol.4, No.1, February 2019, 87-100 DOI: http://dx.doi.org/10.30659/e.4.1.87-100

Panduan Proposal Writing dan Skripsi. (2016). Semarang: SA-PRESS.

Pajares, F. (2003). Self-Efficacy Beliefs, Motivation, and Achievement in Writing: A Review of the Literature. Journal of Reading \& Writing Quarterly.

Pajares, F., \& Johnson, M. J. (1994). Confidence and Competence in Writing: The Role of Self -Efficacy, Outcome Expectancy, and Apprehension. Research in the Teaching of English, Vol. 28, No. 3.

Saleh, M. (2008). Enam Tradisi Besar Penelitian Bahasa. Semarang: UNNES PRESS.

Setiyadi, B. (2006). Metode Penelitian untuk Bahasa Asing. Yogyakarta: Graha Ilmu.

Sugiyono. (2014). Metode Penelitian Pendidikan Pendekatan Kuantitatif, Kualitatif, dan $R \& D$. Bandung: Alfabeta. 